\title{
JUVENILE-MATURE WOOD EVALUATION ALONG THE BOLE CONSIDERING THE INFLUENCE OF SILVICULTURAL TREATMENTS
}

\author{
Antonio Ruano ${ }^{1, \mathrm{~s}}$ \\ https://orcid.org/0000-0002-9684-1458 \\ Eva Hermoso ${ }^{2,3}$ \\ https://orcid.org/0000-0002-0439-6319
}

\begin{abstract}
Wood used for structural purposes has increased in the last decade in Spain. However, as raw material, wood needs to comply with requirements that are not always present. Knowledge about the wood quality from the trees on the stand is essential for providing feedback to forest managers and for taking the required actions to obtain suitable silviculture treatments. Two of the main wood species used in construction in Spain, Pinus nigra and Pinus sylvestris, have been studied in order to determine the amount of juvenile wood, which has been identified as a harmful characteristic for its decrease in quality of the physical-mechanical properties of these species. Being relevant for the best quality of timber in the part along the bole where the logs are obtained, the distribution of juvenile wood at different heights and the effect of several silvicultural treatments have had on juvenile wood formation has been considered. The juvenile-mature wood boundary (transition year) was calculated through segmented linear mixed models employing as variables annual latewood density, obtained through micro X-ray densitometry, silvicultural practices, and a drought index. The results show how juvenile and mature wood is distributed along the bole and the proportion of juvenile wood. Its reduction according to the different thinning and pruning silvicultural practices is presented.
\end{abstract}

Keywords: Juvenile wood, Pinus sylvestris, Pinus nigra, silvicultural treatments, X-ray densitometry, wood quality.

\section{INTRODUCTION}

On wood used for structural purposes, the properties from round wood lumber are decisive in terms of complying with construction standards. With the increasing demand in Europe for construction timber, the importance of wood quality in the sawn timber industry is essential.

Due to changes in forest management and improved genetic material, rotation periods have been reduced as growth rates have increased. However, as a result of this, the trees have a different proportions of anatomical and wood structures deriving into a significant reduction in their mechanical properties (Dowse and Wessels 2013, Wessels et al. 2014, Hermoso et al. 2016). As these problems arose, there have been several researches carried out on wood quality, related to wood density and MFA (micro fibril angle) being the two most influential properties for predicting mechanical properties (Tsoumis 2009, Burdon et al. 2001, Auty et al. 2014, Moore et al. 2015, Mäkinen and Hynynen 2012). The impact of silvicultural interventions and planting density not only affects growth and therefore, wood volume; but also, how straight the bole is, the type and amount 
of branches, as well as its internal characteristics (Ulvcrona and Ahnlund 2011, Mörling 2002, Barbour et al. 1994, Rais et al. 2014, Erasmus et al. 2018).

One characteristic of conifers is that on the first rings growing near the pith, the wood that is formed has different properties than that which is farther from it. This area of wood is called juvenile wood (JW), which is distinguished by less dense and higher MFA, among other properties, and thus, poorer elasto-mechanical properties (Larson 1969, Burdon et al. 2004). When density, MFA and the other properties stabilizes over the years, it is considered to be mature wood (MW).

Although JW it's the name still used by users of this material in Spain, on the wood scientific community the nomenclature for this inner part of the bole has been modified, calling it corewood $(\mathrm{CW})$ and the outer part outerwood (OW) (Burdon et al. 2004). The new nomenclature allows explaining the variation that happens along the bole as the hydraulic and mechanical demands change through the life of the tree (Lachenbruch et al. 2011). In this paper, the terms JW/MW will be used to differentiate two areas of the density radial pattern along the bole. The JW will be defined as the area where its density increases really fast and the MW the area when the density values more or less stabilizes.

As density can be measured easily with high resolution using micro X-ray densitometry, this study was carried out using this methodology considering the annual variation in latewood density (LWD) as the dependent variable (Sauter et al. 1999, Gapare et al. 2006) on a segmented mixed linear model for estimating the transition between JW and MW.

The objective of this paper is to analyze the proportion of juvenile wood along the bole and compare results between plots that have different silviculture regimes on two of the Pinus species used for structural purposes in Spain, Pinus nigra (Black pine) (P. nigra) and Pinus sylvestris (Scots pine) (P. sylvestris).

\section{MATERIALS AND METHODS}

\section{Sampling}

Two different thinning and pruning trials established by INIA-CIFOR at the end of the past century, were used for obtaining the wood samples.

The first site is a pure plantation of Pinus nigra Arnold subsp. Pinus nigra (Black pine) (P. nigra) located in the municipality of Zarzuela de Jadraque (Guadalajara, Spain) $\left(41^{\circ} 1^{\prime} \mathrm{N}, 3^{\circ} 4^{\prime} \mathrm{W}\right)$. It was planted in 1962 and consists of a control, thinning (CFSP) and thinning and $5 \mathrm{~m}$ pruning (CFCP) regimes. The silviculture operations were carried out in 1993 and 2006. It is located at an altitude of 1005 meters above sea level (m.a.s.l.), on a generally flat area with a $1 \%-10 \%$ slope in the NW direction. In this area, the average annual rainfall is $489 \mathrm{~mm}$ and the average annual temperature is $10,9{ }^{\circ} \mathrm{C}$ (AEMET 2017).
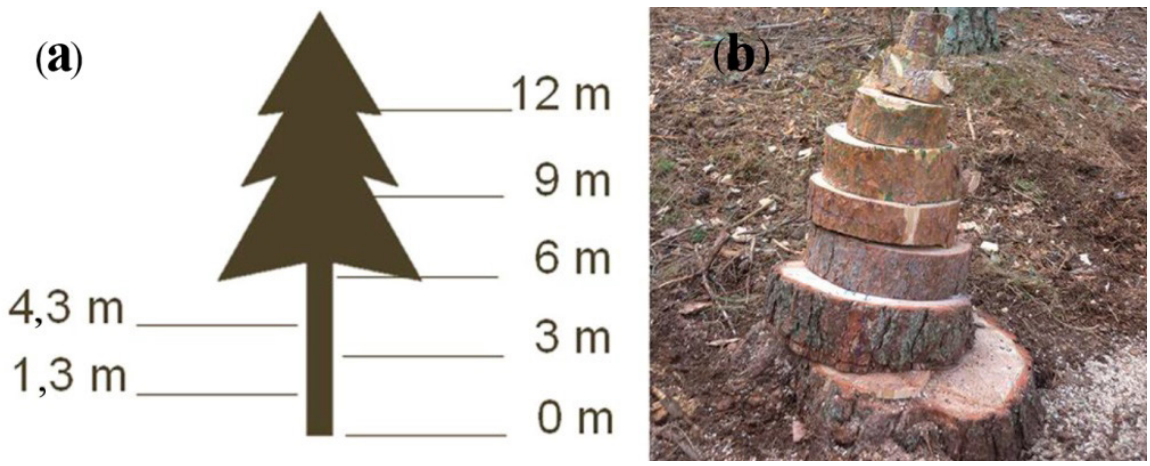

Figure 1: Disk sampling from each tree. (a) Sketch showing the sampled heights (b) Disks obtained from a sampled tree. 
For the P. nigra 12 trees were felled, four trees per treatment. Then disks at basal height $(0,2 \mathrm{~m})$ and at every $3 \mathrm{~m}$ were extracted until the diameter was less than $7,5 \mathrm{~cm}$, plus another two disks were extracted at 1 , $3 \mathrm{~m}$ and at 4,3 $\mathrm{m}$ as described in Figure 1. These extra heights represent breast height and the sampling at 4,3 $\mathrm{m}$ was chosen to have more information of the most valuable sawlogs, which usually is 6 meters. In this paper, the study was carried on up to a height of $12 \mathrm{~m}$, which all trees reached.

The second site is a Pinus sylvestris L. (Scots pine) (P. sylvestris) pure plantation located in the Guadarrama mountain range, in the La Morcuera Forest (Madrid, Spain) (40 $\left.50^{\prime} \mathrm{N}, 3^{\circ} 5^{\prime} \mathrm{W}\right)$. This forest stand comes from a plantation done in 1954 where control, light thinning (CDSP), light thinning and $3 \mathrm{~m}$ pruning (CDP3), heavy thinning (CFSP) and heavy thinning and $5 \mathrm{~m}$ pruning (CFP5) trials had carried out the silviculture treatments in 1991 and 2001. It is located at an altitude of 1550 m.a.s.l. on the northern face of the mountain with a NE orientation and a $10 \%-50 \%$ slope in the trial area. In this area, the average annual rainfall is $1062 \mathrm{~mm}$ and the average annual temperature is $7{ }^{\circ} \mathrm{C}$ (AEMET 2017).

Here, 15 trees were felled, three trees per treatment, and disks were extracted as in the black pine methodology described above, except for the disks at heights of $1,3 \mathrm{~m}$ and $4,3 \mathrm{~m}$.

The silviculture specific data are detailed in Moreno et al. (2014), since here the main goal is just to compare different silvicultural treatments.

From all the disks, $2 \mathrm{~mm}$-thick and $40 \mathrm{~mm}$-wide strips, cut from the cross section were sawn, avoiding compression wood if possible. This was done by obtaining the strips perpendicular to the slope and visually checking for compression wood. Once these strips had been obtained, they were immersed in n-Pentane for 48 $\mathrm{h}$ to eliminate extractives (Gapare et al. 2006, Rodríguez and Ortega 2006). Then, the samples were stored in a climatic chamber at $20{ }^{\circ} \mathrm{C}$ and at $65 \%$ RH until their moisture content was $12 \%$. Later they were scanned with an X-ray to assess the microdensity of the strip using the same equipment as described in Rodríguez and Ortega (2006). The images were processed using LIGNOVISION ${ }^{\mathrm{TM}}$ and TSAP-Win ${ }^{\mathrm{TM}}$ software. A fixed boundary between earlywood and latewood was set as being half the variation in density in each ring, and other average values for each growth ring such as ring width, mean ring density, earlywood width, earlywood density, latewood width, latewood density and, texture were obtained.

\section{Juvenile wood ratio}

In order to assess the proportion of juvenile-mature wood, the transition year (TY) between them needs to be accurately determined. To do so, latewood density (LWD) was the wood characteristic selected, based on previous studies and results (Ruano et al. 2019, Sauter et al. 1999, Gapare et al. 2006).

A two-step procedure was carried out. First, an initial TY was estimated with the "segmented" (Muggeo 2008) package in R (R Core Team 2017) linking yearly LWD at each height to the Standardized Precipitation Evapotranspiration Index (SPEI)(Beguería et al. 2014, De Cáceres et al. 2018)and age, excluding the treatment. This was done to account for the density variation produced by severe droughts (Arzac et al. 2018). Next, the best fitted model was run through the function developed in $\mathrm{R}$ for mixed segmented models (Muggeo et al. 2014, Muggeo 2017), taking into account all the variables (SPEI, age, slope, distance from the crown, sampled height, distance to the top and silvicultural treatments).

In this way the TY was obtained and, in turn, the proportion of JW from the average of both diametrical strips of the disk (one on each side of the pith) along each bole was calculated.

The percentage that resulted at each height was calculated taking into consideration treatments in order to analyze if these had an influence on juvenile wood growth patterns. The volume was also calculated between each tree height sampled using the Smalian method for cubication. Also, the taper was calculated by the angle produced between each disc extracted.

\section{RESULTS AND DISCUSSION}

The results will be presented separately for each species. 


\section{Pinus nigra}

Figure 2 shows TY for different treatments and heights on Pinus nigra Arn. and over the boxplot the average transition age per treatment. When these results were analyzed, they showed that TYs were produced before the first silvicultural intervention was carried out. Due to this, the result regarding how silvicultural influenced TY occurrence, cannot be evaluated.

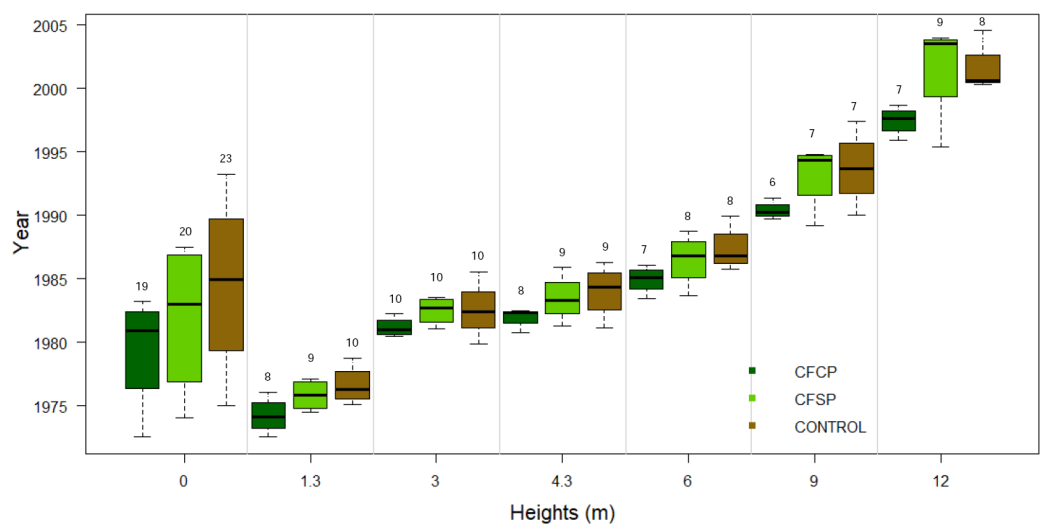

Figure 2: Transition year per treatment on P. nigra plots and average transition age.

However, this figure expresses the TY progress produced at different heights. At the basal height the TY varied a lot among trees, being achieved sometimes even later than further up the bole, this could be due to the mechanical demands and the proximity to the root system (Lachenbruch et al. 2011), if only one measurement can be done per tree, basal height should not be the height chosen. At a height of $12 \mathrm{~m}$, a slight difference between the CFCP and the control group was observed, but the crown proximity might have influenced this result.

To the better analysis of JW produced at each height, in Figure 3 the percentage of JW is compared per plot type and some differences could be observed. Due to the increase in radial growth brought about by late thinning, the extent of MW length at each height increased and so the percentage of JW in respect to the total reduced. There also seemed to be a difference between thinning and $5 \mathrm{~m}$ pruning (CFCP) and thinning (CFSP) inside the crown at a height of $12 \mathrm{~m}$, which occurs because in the thinned without pruning plots the percentage of JW increases slightly more compared with the pruned ones. This effect is in keeping with the findings of Larson (1969).
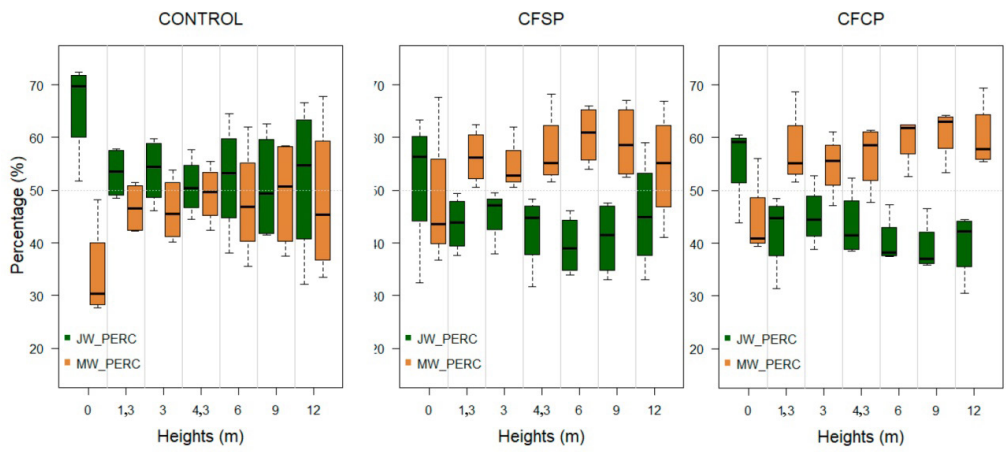

Figure 3: P. nigra percentage in the radial length of JW and MW at each height per treatment. 
An analysis from a perspective of volume is presented in Table 1. Note the difference in terms of total volume per treatment applied in comparison with that for the control group, as the MW is affected by late thinning, as mentioned previously. There is not a significant difference between CFSP and CFCP in terms of total volume and the percentage of JW.

Table 1: P. nigra average volume in $\mathrm{m}^{3}$ per plot type and JW volume percentage.

\begin{tabular}{|c|c|c|c|c|c|c|}
\hline Height & Plot type & JW Volume & MW Volume & Tree Volume & $\%$ JW Volume & SD \\
\hline $0-12$ & CONTROL & 0,057 & 0,132 & 0,189 & 30 & $5,9^{\mathrm{a}}$ \\
\hline $0-12$ & CFSP & 0,062 & 0,269 & 0,331 & 19 & $4,3^{\mathrm{b}}$ \\
\hline $0-12$ & CFCP & 0,065 & 0,286 & 0,351 & 18 & $3,4^{\mathrm{b}}$ \\
\hline
\end{tabular}

a,b Statistical Significance groups, equal letters indicate no significant difference between treatments, according to Tukey HSD Test $(\mathrm{p} \leq 0,05)$.

Figure 4 shows a reconstructed tree per treatment with its radial section area of JW-MW along the bole based on the medium length strips from the disks extracted at the different heights.

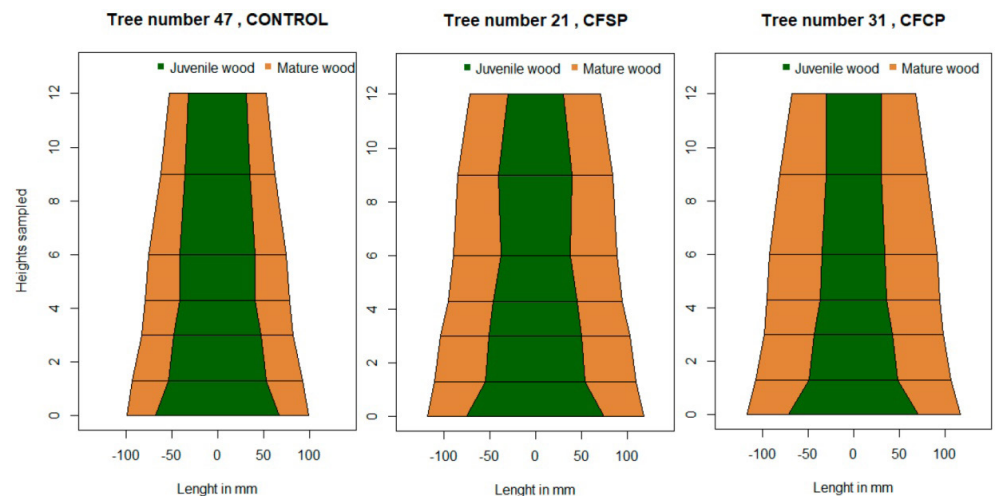

Figure 4: P. nigra JW/MW tree reconstruction along the bole.

In this figure is also detected better results on taper for CFCP treatment than those for CFSP, mainly in the $3 \mathrm{~m}-6 \mathrm{~m}$ section of the bole, where when bucked to a specific merchantable length, sawmills can obtain products for structural use and therefore high quality is required.

There have been reports in the literature concerning the effects of thinning and pruning but depending on the variable measured, the age at which they are applied and their intensity, different effects can be seen (Peltola et al. 2007, Amateis and Burkhart 2011, Ulvcrona and Ahnlund 2011, Vincent et al. 2011, Pape 1999, Mazet et al. 1990, Moore et al. 2015, Mörling 2002, Dobner et al. 2018, Barbour et al. 1994, Burkhart and Amateis 2020, Paul 1958). Even so, most of these reports conclude that these effects are limited to the following few years after treatment. So, if this is considered, clearly thinning and pruning operations applied after the TY is reached, in addition of increase total volumes in Mediterranean forests also will increase the percentage of quality wood obtained from them.

\section{Pinus sylvestris}

Similar to the P. nigra results, the TY determined in P. sylvestris was produced before silviculture treatments so it cannot be used to detect differences between them and control plots.

Figure 5 presents results of TY tendency obtained according to treatment and heights and over the boxplot the average transition age per treatment. At $12 \mathrm{~m}$, there is a significant difference between the pruned and the control trees, but there is none for the heavy thinned trees (CFSP) without pruning. 


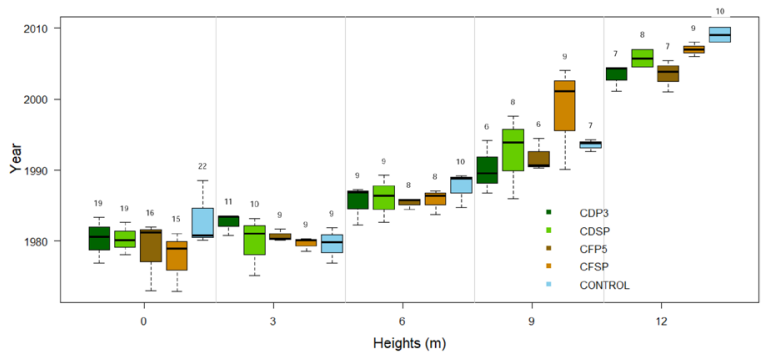

Figure 5: TY per treatment on $P$. sylvestris plots and average transition age.

On comparing the percentage of JW to MW at each height when the plot type is taken into consideration, somedifferencescanalsobeobserved(Figure 6). Dueto theincreaseinradial growth producedbylate thinning, the MW length at each height increased, so the percentage of JW decreased, as in $P$. nigra. No explanation has been found for the marked variations of both wood percentage at $9 \mathrm{~m}$ in the control group.
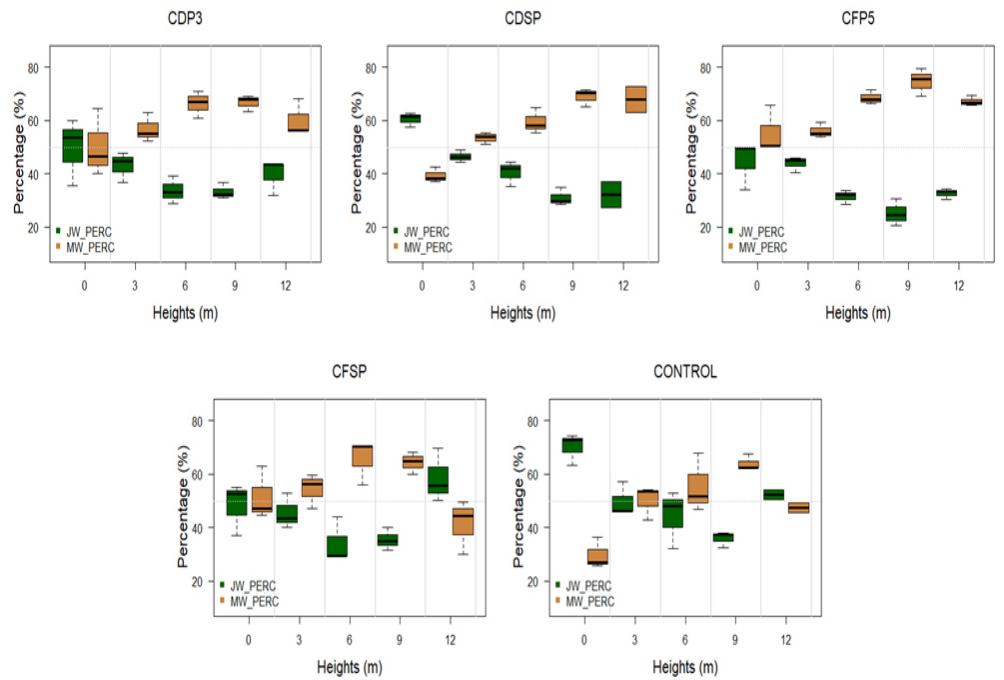

Figure 6: $P$. sylvestris percentage in radial length of JW and MW at each height per treatment.

Regarding the total volume of each wood type, significat differences can be observed in terms of the volume per treatment in Table 2. Note the JW volume percentage decrease with the silvicultural treatments applied versus control. This is due to the mentioned increase in the volume of MW with respect to the total volume, but with very similar results between light thinning and strong thinning.

Regarding the percentage of JW obtained from different pruning for $P$. sylvestris trees, it can be observed close results between both, $17 \%$ for 3 meters and $15 \%$ for 5 meters pruning.

Table 2: P. sylvestris volume in $\mathrm{m}^{3}$ per plot type and JW volume percentage.

\begin{tabular}{|c|c|c|c|c|c|c|}
\hline Height & Plot type & JW Volume & MW Volume & Tree Volume & \% JW Volume & SD \\
\hline $0-12$ & CONTROL & 0,065 & 0,150 & 0,215 & 30 & $3,8^{\text {a }}$ \\
\hline $0-12$ & CDSP & 0,069 & 0,255 & 0,325 & 21 & $1,5^{\text {b }}$ \\
\hline $0-12$ & CDP3 & 0,061 & 0,396 & 0,476 & 17 & $4,4^{\text {bc }}$ \\
\hline $0-12$ & CFSP & 0,056 & 0,251 & 0,307 & 19 & $4,0^{\text {bc }}$ \\
\hline $0-12$ & CFP5 & 0,063 & 0,369 & 0,432 & 15 & $1,5^{\mathrm{c}}$ \\
\hline
\end{tabular}

a,b Statistical Significance groups, equal letters indicate no significant difference between treatments, according to Tukey HSD Test $(\mathrm{p} \leq 0,05)$. 
In Figure 7 it is presented a reconstructed tree with the area of JW-MW on a radial section based on data yielded from the medium length strips obtained for each height and silvicultural treatment.

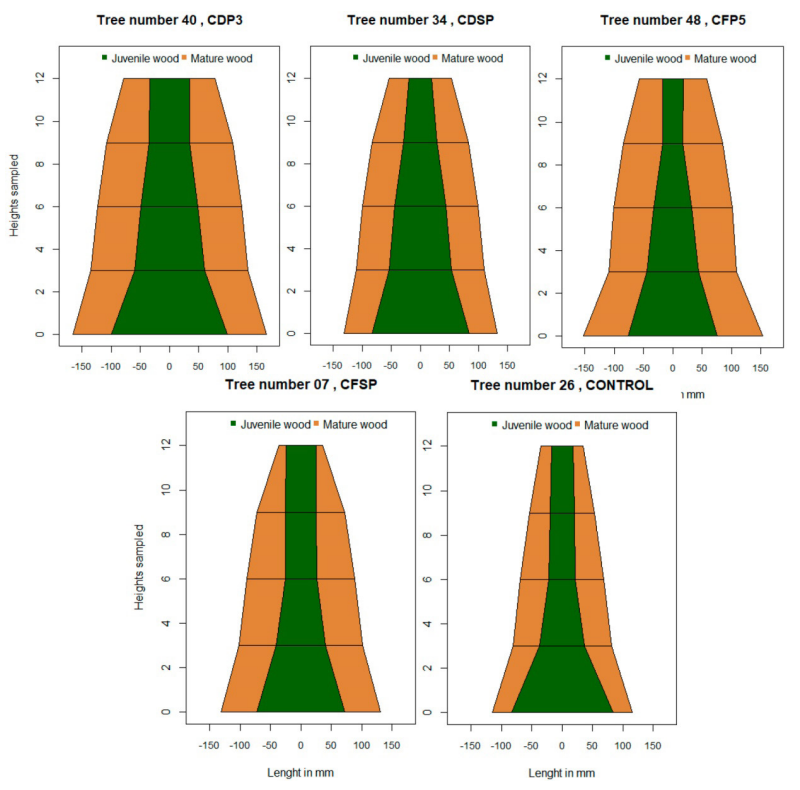

Figure 7: P. sylvestris JW/MW tree reconstruction along the bole.

Furthermore, it can be seen again that the volume of JW reduces with treatments applied versus control due to the previously mentioned increase in the volume of MW with respect to the total volume. Stronger thinning combined with $5 \mathrm{~m}$ pruning produces a greater reduction in the volume of JW (CFP5). Another advantage of applying this latter treatment is that it generates clearwood, wich is important in terms of wood quality for structural use. This was observed on plots on both species which is also in accordance with the findings of Larson et al. (2001).

On P. sylvestris, while pruning at $5 \mathrm{~m}$ seems to influence the degree of taper, pruning at $3 \mathrm{~m}$ seems to have no clear effect on it probably because the branches removed were declining or dying branches (Larson 1969) or already dead, as carrying out this treatment is costly, either performing late pruning enhanced up to $5 \mathrm{~m}$ or not doing it at all, should be considered.

\section{CONCLUSIONS}

The Juvenile wood volume of $P$. nigra and $P$. sylvestris is not significantly decreased at most heights of the bole when thinning and pruning treatments are performed after the TY occurrence. However, due to the tree volume increase produced in the MW on the thinned trees, the total tree percentage of JW volume is reduced. Related to P. nigra, the pruning influence on the JW volume is only significant at $12 \mathrm{~m}$ height but the crown might be an influencing factor of this result. Nevertheless, thinning and pruning to $5 \mathrm{~m}$ is costly but they reduce juvenile wood, tapper and knots which makes this silvicultural practice worth it. For P. sylvestris, the results of JW volume percentage are very similar for $3 \mathrm{~m}$ and $5 \mathrm{~m}$ pruning, but it has to be considered also the better wood quality production (knotless and tapper). As stated in many papers in the literature, results may vary with the intensity and time of the thinning, as well as on the amount of green pruning carried out. Additional research is required to support these results, for example using MFA analysis or being supplemented with some destructive sampling. Studies should be also performed when silviculture treatments are previous to reach the TY.

\section{ACKNOWLEDGEMENTS}

This study has been carried out with the support of the Ministry of Economy and Competitivity of the Government of Spain through the Project RTA2014-00005-00-00. The authors would like to thank Enrique Garriga and Ramon García who helped us on the fieldwork, to Juan Carlos Cabrero who came up with creative ways on how to proceed, to Eduardo Trobajo who did the $\mu \mathrm{XRD}$ and to the carpenter Emilio Camacho who made the processing of the samples possible. 


\section{REFERENCES}

AEMET. 2017. Climatic data. AEMET, Ministry of Agriculture, Food and Environment: Spain. http://www.aemet.es/

Auty, D.; Achim, A.; Macdonald, E.; Cameron, A.D.; Gardiner, B.A. 2014. Models for predicting wood density variation in Scots pine. Forestry 87(3): 449-458. https://doi.org/10.1093/forestry/cpu005

Amateis, R.; Burkhart, H. 2011. Growth of young loblolly pine trees following pruning. For Ecol Manag 262: 2338-2343. https://doi.org/10.1016/j.foreco.2011.08.029

Arzac, A.; Rozas, V.; Rozenberg, P.; Olano, J.M. 2018. Water availability controls Pinus pinaster xylem growth and density: A multi-proxy approach along its environmental range. Agric For Meteorol 250-251: 171180. https://doi.org/10.1016/j.agrformet.2017.12.257

Barbour, R.J.; Fayle, D.C.F.; Chauret, G.; Cook, J.; Karsh, M.B.; Ran, S. 1994. Breast-height relative density and radial growth in mature jack pine (Pinus banksiana) for 38 years after thinning. Can J For Res 24(12): 2439-2447. https://doi.org/10.1139/x94-315

Beguería, S.; Vicente-Serrano, S.M.; Reig, F.; Latorre, B. 2014. Standardized precipitation evapotranspiration index (SPEI) revisited: parameter fitting, evapotranspiration models, tools, datasets and drought monitoring. Int J Climatol 34(10): 3001-3023. https://doi.org/10.1002/joc.3887

Burdon, R.D.; Britton, R.A.J.; Walford, G.B. 2001. Wood stiffness and bending strength in relation to density in four native provenances of Pinus radiata. N Z J For Sci 31(1): 130-146. https://www.scionresearch. com/__data/assets/pdf_file/0012/17013/Reprint-2759.pdf

Burdon, R.D.; Kibblewhite, R.P.; Walker, J.C.F.; Mcgraw, R.A.; Evans, R.; Cown, D.J. 2004. Juvenile versus mature wood: A new concept, orthogonal to corewood versus outerwood, with special reference to Pinus radiata and Pinus taeda. For Sci 50(4): 399-415. https://www.scopus.com/record/display. uri?eid=2-s2.0-4644337108\&origin=inward\&txGid=d7b6ec2b7e416f7637c28b97bed012e1

Burkhart, H.; Amateis, R. 2020. Effects of early pruning on ring specific gravity in young loblolly pine trees. Wood Fiber Sci 52(2): 139-151. https://doi.org/10.22382/wfs-2020-013

De Cáceres, M.; Martin-StPaul, N.; Turco, M.; Cabon, A.; Granda, V. 2018. Estimating daily meteorological data and downscaling climate models over landscapes. Environmental Modelling \& Software 108: 186-196. https://doi.org/10.1016/j.envsoft.2018.08.003

Dobner, M.; Huss, J.; Tomazello Filho, M. 2018. Wood density of loblolly pine trees as affected by crown thinnings and harvest age in southern Brazil. Wood Sci Technol 52:465-485. https://doi.org/10.1007/ s00226-017-0983-9

Dowse, G.P.; Wessels, C.B. 2013. The structural grading of young South African grown Pinus patula sawn timber. South For J For Sci 75(1): 7-17. https://doi.org/10.2989/20702620.2012.743768

Erasmus, J.; Kunneke, A.; Drew, D.M.; Wessels, C.B. 2018. The effect of planting spacing on Pinus patula stem straightness, microfibril angle and wood density. Forestry 91(3): 247-258. https://doi.org/10.1093/ forestry/cpy005

Gapare, W.J.; Wu, H.X.; Abarquez, A. 2006. Genetic control of the time of transition from juvenile to mature wood in Pinus radiata D. Don. Ann For Sci 63(8): 871-878. https://doi.org/10.1051/forest:2006070

Hermoso, E.; Mateo, R.; Íñiguez-González, G.; Montón, J.; Arriaga, F. 2016. Visual Grading and Structural properties assessment of large cross-section Pinus radiata D. Don Timber. BioRes 11 (2): $5312-$ 5321. https://doi.org/10.15376/biores.11.2.5312-5321

Larson, P.R. 1969. Wood formation and the concept of wood quality. New Haven, CT: Yale University, School of Forestry, Bulletin 74: 54. https:/www.fs.usda.gov/treesearch/pubs/49814 
Larson, P.R.; Kretschmann, D.E.; Clark, A.I.; Isebrands, J.G. 2001. Formation and properties of juvenile wood in southern pines: a synopsis. Gen Tech Rep FPL-GTR-129. USDA For Serv Forest Prod Lab: Madison, WI. 42. https://doi.org/10.2737/FPL-GTR-129

Lachenbruch, B.; Moore, J.R.; Evans, R. 2011. Radial variation in wood structure and function in woody plants, and hypotheses for its occurrence. In: Meinzer, F.C.; Lachenbruch, B.; Dawson, T.E. (eds) Size- and Age-Related Changes in Tree Structure and Function. Tree Physiol. Springer: Dordrecht, 4:121-164. https://doi.org/10.1007/978-94-007-1242-3_5

Mäkinen, H.; Hynynen, J. 2012. Predicting wood and tracheid properties of Scots pine. Forest Ecology and Management 279: 11-20. https://doi.org/10.1016/j.foreco.2012.05.024

Mazet, J.F.; Nepveu, G.; Velling, P.; Deret-Varcin, E. 1990. Etude des effets de quelques paramètres sylvicoles et environnementaux sur la densité du bois de l'Epicéa commun, du Sapin pectiné et du Pin sylvestre dans le Nord-Est de la France. Actes du Troisième Colloque Sciences et Industries du Bois, ARBORA Bordeaux, 537-546.

Moore, J.R.; Cown, D.J.; McKinley, R.B.; Sabatia, C.O. 2015. Effects of stand density and seedlot on three wood properties of young radiata pine grown at a dry-land site in New Zeland. N Z J For Sci 45(1): 4. https://doi.org/10.1186/s40490-015-0035-x

Mörling, T. 2002. Evaluation of annual ring width and ring density development following fertilisation and thinning of Scots pine. Ann For Sci 59(1): 29-40. https://doi.org/10.1051/forest:2001003

Moreno, D.; Sánchez, M.; Álvarez, J.; Hevia, A.; Majada, J.; Cañellas, I.; Gea, G. 2014. Response to the interaction of thinning and pruning of pine species in Mediterranean mountains. Eur J Forest Res 133: 833-843. https://doi.org/10.1007/s10342-014-0800-z

Muggeo, V.M. 2008. Segmented: An R Package to Fit Regression Models with Broken-Line Relationships. $R$ News 8(1): 20-25. http://mirrors.nics.utk.edu/cran/doc/Rnews/Rnews_2008-1.pdf\#page=20

Muggeo, V.M.; Atkins, D.C.; Gallop, R.J.; Dimidjian, S. 2014. Segmented mixed models with random changepoints: a maximum likelihood approach with application to treatment for depression study. Stat Model 14(4): 293-313. https://doi.org/10.1177/1471082X13504721

Muggeo, V.M. 2017. Interval estimation for the breakpoint in segmented regression: a smoothed score-based approach. Aust NZ J Stat 59(3): 311-322. https://doi.org/10.1111/anzs.12200

Peltola, H.; Kilpeläinen, A.; Sauvala, K.; Räisänen, T.; Ikonen, V.P. 2007. Effects of early thinning regime and tree status on the radial growth and wood density of Scots pine. Silva Fenn 41(3): 285. https://doi.org/10.14214/sf.285

Pape, R. 1999. Influence of Thinning and Tree Diameter Class on the Development of Basic Density and Annual Ring Width in Picea abies. Scandinavian Journal of Forest Research 14(1): 27-37. https://doi.org/10.1080/02827589908540806

Paul, B.H. 1958. Specific gravity changes in southern pines after release. South Lumberman 197(2465): $122-124$

R Core Team 2017. R: A language and environment for statistical computing. R Foundation for Statistical Computing: Vienna, Austria. https://www.r-project.org/

Rais, A.; Poschenrieder, W.; Pretzsch, H.; Van De Kuilen, J.W.G. 2014. Influence of initial plant density on sawn timber properties for Douglas fir (Pseudotsuga menziesii (Mirb.) Franco). Ann For Sci 71(5): 617-626. https://doi.org/10.1007/s13595-014-0362-8

Rodríguez, E.; Ortega, M. 2006. Tendencias radiales de la densidad y sus componentes en Pinus nigra Arn. de la Península Ibérica. Forest Sys 15(1):120-133. http://www.inia.es/gcontrec/pub/RODRIGUEZ-ORTEGA_1144740778140.pdf 
Ruano, A.; Ruiz-Peinado, R.; Fernández-Golfín, J.; Hermoso, E. 2019. Height growth for assessing core-outer wood transition on Pinus sylvestris and Pinus nigra Spanish stands. Eur J For Res 1-6. https://doi.org/10.1007/s10342-019-01231-0

Sauter, U.H.; Mutz, R.; Munro, B.D. 1999. Determining juvenile-mature wood transition in Scots pine using latewood density. Wood Fiber Sci 31(4): 416-425. https://wfs.swst.org/index.php/wfs/article/ view/2139/2139

Tsoumis, G.T. 2009. Science and technology of wood: structure, properties, utilization. Van Nostrand Reinhold: New York, EEUU. https://www.trae.dk/wp-content/uploads/2001/10/science-and-technology-of-wood.pdf

Ulvcrona, T.; Ahnlund, U.K. 2011. The effects of pre-commercial thinning and fertilization on characteristics of juvenile clearwood of Scots pine (Pinus sylvestris L.). Forestry 84(3): 207-219. https://doi.org/10.1093/forestry/cpr007

Vincent, M.; Krause, C.; Koubaa, A. 2011. Variation in black spruce (Picea mariana (Mill.) BSP) wood quality after thinning. Ann For Sci 68(6): 1115-1125. https://doi.org/10.1007/s13595-011-0127-6

Wessels, C.B.; Malan, F.S.; Nel, D.G.; Rypstra, T. 2014. Variation in strength, stiffness and related wood properties in young South African-grown Pinus patula. South For J For Sci 76(1): 37-46. https://doi.org/10.2 989/20702620.2013.870406

\section{LIST OF ABBREVIATIONS}

MFA - Micro Fibril Angle

JW - Juvenile Wood

MW - Mature Wood

CW - Corewood

OW - Outerwood

LWD - Latewood density

CFSP - Plots with the thinning trials for the black pines

CFCP - Plots with the thinning and $5 \mathrm{~m}$ pruning trials for the black pines

m.a.s.l. - Meters above the sea level

CDSP - Plots with the light thinnings trials for the Scots pines

CDP3 - Plots with the light thinnings trials and $3 \mathrm{~m}$ pruning for the Scots pines

CFSP - Plots with the heavy thinnings trials for the Scots pines

CFP5 - Plots with the heavy thinnings trials and $5 \mathrm{~m}$ pruning for the Scots pines

TY - Transition year

SPEI - Standardized Precipitation Evapotranspiration Index 